\title{
Increased Performance of Single-Chamber Air Cathode Microbial Fuel Cell Using Power Management System
}

\author{
Longsheng QIAO \\ School of Environment and Chemical Engineering \\ Tianjin Polytechnic University \\ State Key Laboratory of Separation Membranes and \\ Membrane Processes \\ Tianjin Polytechnic University \\ Tianjin, 300387, China \\ e-mail: 18222776303@163.com \\ Ben'ai CHENG \\ School of Environment and Chemical Engineering \\ Tianjin Polytechnic University \\ State Key Laboratory of Separation Membranes and \\ Membrane Processes \\ Tianjin Polytechnic University \\ Tianjin, 300387, China

\section{Zhichao HE} \\ School of Environment and Chemical Engineering \\ Tianjin Polytechnic University \\ Tianjin, 300387, China
}

\author{
Zhiwei XIAO \\ Environmental Protection Centre \\ The Administration of Transport \\ Beijing, 100013, China \\ e-mail: xiaozw311@ hotmail.com
}

\author{
Zhengyuan TAO \\ School of Environment and Chemical Engineering \\ Tianjin Polytechnic University \\ Tianjin, 300387, China
}

\author{
Jie WANG \\ School of Environment and Chemical Engineering \\ Tianjin Polytechnic University \\ State Key Laboratory of Separation Membranes and \\ Membrane Processes \\ Tianjin Polytechnic University \\ Tianjin, 300387, China
}

\begin{abstract}
Electricity generation by single-chamber air cathode fuel cells (MFCs) is considerably influenced by power management system(PMS). This study showed that application of PMS connected with a single-chamber air cathode MFC significantly improved its columbic efficiencies (CEs), current, and power output. In MFC tests based on PMS, the optimal COD of influent was $400 \mathrm{mg} / \mathrm{L}$, achieving the highest $\mathrm{CE}$ $(4.59 \%)$ and the optimal COD of influent $800 \mathrm{mg} / \mathrm{L}$ with the highest harvesting efficiency $(9.80 \%)$, which were higher than those in MFCs connecting resistors. The ranges of voltage output and power out of MFC based on PMS were $1.60 \sim 2.00$ $\mathrm{V}, 2.56 \sim 4.00 \mathrm{~mW}$, higher than those in MFCs with resistors, while low COD prolonged charge time. PMS improved MFC performance, and both of the electricity generation of MFC and the harvesting efficiency should be considered.
\end{abstract} system

Keywords-microbial fuel cell; COD; power management

\section{INTRODUCTION}

MFCs are bioreactors that use bacteria as the catalysts to directly catalyze the conversion of organic matter to generate current [1]. Electrons produced by the exoelectrogens from the substrates on the anode flow to the cathode across resistors. The open circuit voltage (OCV) of MFCs is lower than $1.20 \mathrm{~V}$. Moreover, its power output is lower than $2 \mathrm{~mW}$. Thus there is a gap between the power output of MFC and real word applications. And many researches had focused on collecting MFC electricity by PMS to replace chemical battery to power sensors, such as temperature humidity sensors, wireless telecommunication systems, and submersible ultrasonic receivers $[2,3]$.

A PMS was an electronic circuit that could harvest MFC energy and shape it to a usable form. Most studies about MFC based on PMS focused on sensors working, energy harvesting efficiency and etc., while the relationship between PMS and MFC has rarely been studied [4]. This study employed municipal wastewater to investigate the interaction between a PMS and a MFC. $600 \mathrm{mg} / \mathrm{L} \mathrm{COD} \mathrm{of} \mathrm{influent} \mathrm{was}$ supplied to the MFC during inoculation, and the voltage, and current were recorded. Further, resistors were replaced by PMS, and the relationship between pollutant removals of MFC and work of PMS was investigated. Suggestions on MFC electricity generation and energy harvesting were then given. 


\section{MATERIALS AND METHODS}

\section{A. MFC Construction and Operation}

The study used a single-chamber air cathode MFC with an effective anodic chamber volume of $0.88 \mathrm{~L}$. The MFC was fitted with three pieces of carbon felts $\left(384 \mathrm{~cm}^{2}\right.$, Fengxiang Co., China) and carbon cloth cathode $\left(100 \mathrm{~cm}^{2}\right.$, Hesen Co., China) [5]. The distance between two electrodes was $5 \mathrm{~cm}$. The cell voltage and current were recorded every 15 min by a data acquisition (34972A, Keysight Co., USA). The influent flow rate of anode chamber was $0.08 \mathrm{~L} / \mathrm{h}$ using a peristaltic pump (BT100-2J, Longer Co., China). MFC was connected with $1000 \Omega$ resistors during inoculation. After 55 $\mathrm{h}$, the resistance was changed to the PMS for harvesting MFC's electricity. Synthetic wastewater was employed as feed water with influent COD of $200 \sim 1000 \mathrm{mg} / \mathrm{L}$ [5]. The inoculated sludge was taken from Jizhuangzi Wastewater Treatment Plant (Tianjin, China).

\section{B. Power Management System}

The power management system consisted energy harvesting converter and energy harvesting converter controller. Fig 1. shows the block diagram of PMS. The transformer (LPR6235-253PML) and the DC/DC converter (LTC3108-1) increased voltage output of MFC, which stored energy in the super-capacitor (1F) [6]. when the voltage output of capacitor reached $2.0 \mathrm{~V}$, switch turned on; when the voltage output was below $1.60 \mathrm{~V}$, switch turned off.

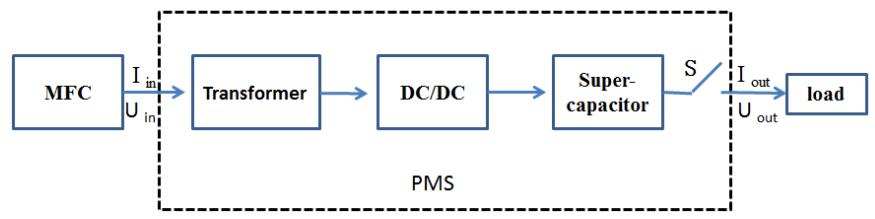

Figure 1. The block diagram of PMS

\section{Test and Analyses}

MFC performance was examined by standard polarization and power density curves [5]. The potential drop across an external resistance was also monitored to determine current using Ohm's law. The power was calculated as $\mathrm{P}=\mathrm{UI}$, where $\mathrm{P}$ is power $(\mathrm{W})$, and $\mathrm{U}$ is voltage (V), and I is current (A). The Chemical Oxygen Demand (COD) was measured according to the standard method. $\mathrm{COD}$ removal was calculated as $\mathrm{ECOD}=\left[\left(\mathrm{COD}_{\mathrm{in}^{-}}\right.\right.$ $\left.\mathrm{COD}_{\text {out }} / \mathrm{COD}_{\text {in }}\right] \times 100 \%$, where $\mathrm{COD}_{\text {in }}$ is the influent $\mathrm{COD}$ and $\mathrm{COD}_{\text {out }}$ the effluent $\mathrm{COD}$, respectively. Columbic efficiency (CE) was calculated as $\mathrm{CE}=\mathrm{C}_{\mathrm{p}} / \mathrm{C}_{\mathrm{t}} \times 100 \%$, where $\mathrm{C}_{\mathrm{p}}$ is the total coulombs calculated by integrating the current over time, and $\mathrm{C}_{\mathrm{t}}$ is the theoretical amount of coulombs available based on COD removed in the MFC.1 The energy harvesting efficiency $(\eta)$ of PMS was calculated as $\eta=$ Eoutput $/ \mathrm{E}_{\mathrm{MFC}} \times 100 \%$, where $\mathrm{E}_{\text {output }}$ is the energy applied on the load and $\mathrm{E}_{\mathrm{MFC}}$ is the energy produced by MFC [3].

\section{RESULTS AND DISCUSSION}

\section{A. Electricity Generation Performance during Inoculation}

The MFC employed synthetic wastewater as feed water at influent COD of $600 \mathrm{mg} / \mathrm{L}$. As the Fig 2. (a) shows, the voltage of MFC increased from $0.15 \mathrm{~V}$ to $0.60 \mathrm{~V}$ at a steady voltage. Polarization and power curves were measured afterwards. As the Fig 2. (b) shows, the peak of power was $1.51 \mathrm{~mW}$ and the internal resistance calculated by the slope of polarization curve was $50.72 \Omega$.

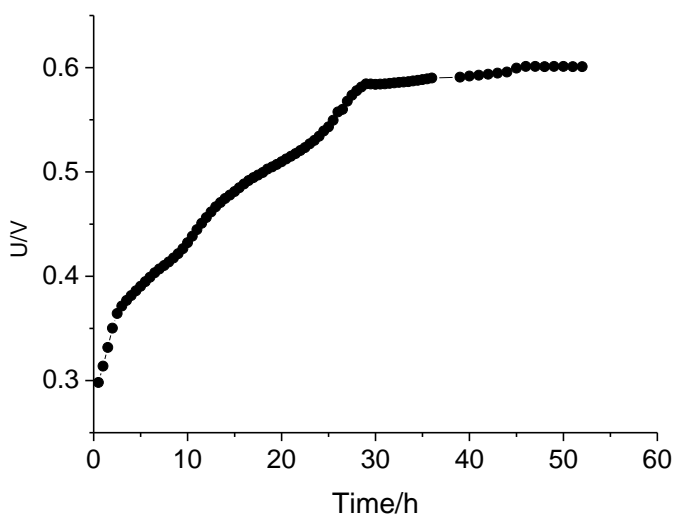

(a)

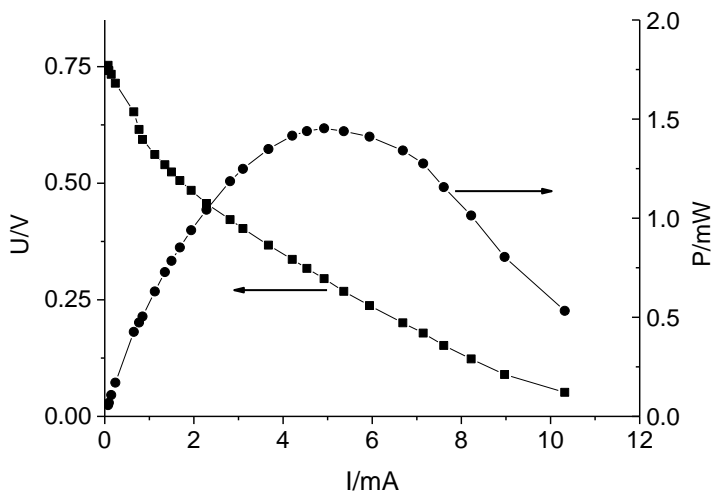

(b)

Figure 2. Performance of MFC during inoculation: (a) Voltage changing with time; (b) Polarization and power curves

Table I shows the COD removal and CE of MFC during inoculation. The COD removal and CE of MFC were $60.10 \%$ and $0.56 \%$ at $12 \mathrm{~h}$, respectively. While the COD removal and CE were about $80 \%$ and $0.59 \%$ after $24 \mathrm{~h}$, respectively. At beginning $(0 \sim 30 \mathrm{~h})$, exoelectrogens in the mixed liquids were went out from the MFC along with the effluent. Thus the bacteria showed a poor utilization ability of carbon source, which led to a low voltage. However, after a short operating time $(30 \sim 55 \mathrm{~h})$, exoelectrogens attached on anode steadily, degrading more organic matters to generate electricity, then voltage increased gradually. The voltage became steady at the end of inoculation period, and electricity generation was limited by carbon sources. 
TABLE I. COD REMOVAL AND CE OF MFC DURING INOCULATION

\begin{tabular}{cccll}
\hline Time $(\mathrm{h})$ & $\mathrm{COD}_{\text {in }}(\mathrm{mg} / \mathrm{L})$ & $\mathrm{COD}_{\text {out }}(\mathrm{mg} / \mathrm{L})$ & $\mathrm{E}_{\mathrm{COD}}(\%)$ & $\mathrm{CE}(\%)$ \\
\hline 12 & 565.4 & 225.6 & 60.10 & 0.56 \\
24 & 558.7 & 121.0 & 78.34 & 0.59 \\
36 & 551.9 & 112.5 & 79.62 & 0.59 \\
48 & 555.3 & 111.1 & 80.00 & 0.59 \\
\hline
\end{tabular}

B. Electricity Generation Performance under Different Concentration of $C O D$

The influent COD concentration was varied from 200 to $1000 \mathrm{mg} / \mathrm{L}$. Table II shows the voltage $\left(\mathrm{U}_{\text {in }}\right)$, current $\left(\mathrm{I}_{\mathrm{in}}\right)$, power $\left(\mathrm{P}_{\text {in }}\right)$ of MFC based on PMS under different COD concentrations. PMS malfunctioned at an extremely low lin of $200 \mathrm{mg} / \mathrm{L} \mathrm{COD}$, so the COD concentrations were set between $400 \sim 1000 \mathrm{mg} / \mathrm{L}$ afterward. The $\mathrm{U}_{\text {in }}, \mathrm{I}_{\text {in }}$, and $\mathrm{P}_{\text {in }}$ increased with the rising concentration between $400 \sim 800$ $\mathrm{mg} / \mathrm{L}$, at steady-stage with higher COD. The maximum values of $U_{\text {in }}$ and $P_{\text {in }}$ were about $180 \mathrm{mV}$ and $0.99 \mathrm{~mW}$, respectively. At a low concentration, electricity generation was limited by carbon sources; at a high concentration, electricity generation was limited by enzymes.

TABLE II. VOLTAGE, CURRENT, AND POWER OF MFC UNDER DIFFERENT COD CONCENTRATIONS

\begin{tabular}{cccc}
\hline $\begin{array}{l}\text { Concentration } \\
(\mathrm{mg} / \mathrm{L})\end{array}$ & $\mathrm{U}_{\text {in }}(\mathrm{mV})$ & $\mathrm{I}_{\text {in }}(\mathrm{mA})$ & $\mathrm{P}_{\text {in }}(\mathrm{mW})$ \\
\hline 200 & 90 & 3.02 & 0.27 \\
400 & 120 & 3.78 & 0.45 \\
600 & 125 & 4.25 & 0.55 \\
800 & 184 & 5.20 & 0.96 \\
1000 & 179 & 6.02 & 0.99 \\
\hline
\end{tabular}

\section{Pollutant Removal under Different COD Concentrations}

Fig 3. shows the COD removal and CE of MFC based on PMS under different COD concentrations. COD removal was marginally affected by COD concentrations, which was about $80 \%$, while CE decreased from $4.59 \%$ to $2.88 \%$ with increasing COD concentrations. At higher COD concentrations, HRT was too short to meet organic complete degradation, leading to a lower CE. When PMS replaced $1000 \Omega$ resistor, current, and CE were increased by $4 \sim 9$ and $5 \sim 10$ times, respectively, comparing with those in MFCs connecting a resistor. With the current increasing and the voltage decreasing, the amount of exoelectrogens on anode became more and the internal resistance smaller. Thus higher current was positive for energy demand of bacteria growth, and CE with PMS was higher than that with resistors.

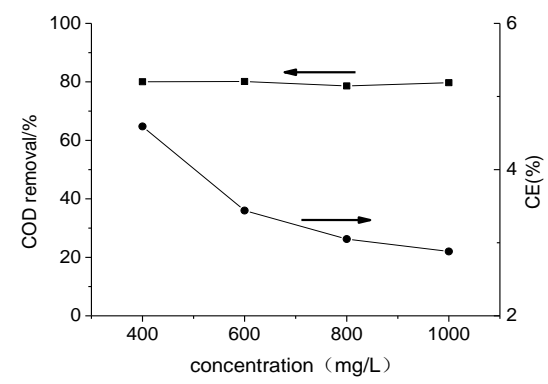

Figure 3. COD removal and CE of MFC under different COD concentrations

\section{Harvesting Efficiency under Different COD Concentrations}

Table III shows energy recovery of PMS under different COD concentrations. During charge state, MFC's electricity was stored in capacitors increasing from $1.60 \mathrm{~V}$ to $2.00 \mathrm{~V}$, and then a capacitor discharged the load across a $1000 \Omega$ resistor decreasing from $2.00 \mathrm{~V}$ to $1.60 \mathrm{~V}$. COD concentrations had no significant effect on discharge time, which was stable at about 4 minutes. Charge time decreased with increasing concentration. The maximum harvesting efficiency $(\eta)$ was $9.80 \%$ at $800 \mathrm{mg} / \mathrm{L}$, the minimum $6.05 \%$ at $1000 \mathrm{mg} / \mathrm{L}$.

TABLE III. ENERGY RECOVERY OF MFC UNDER DIFFERENT COD CONCENTRATIONS

\begin{tabular}{llll}
\hline Concentration(mg/L & $\begin{array}{l}\text { Charge time } \\
\text { (h) }\end{array}$ & $\begin{array}{c}\text { Discharge time } \\
\text { (min) }\end{array}$ & $\begin{array}{l}\eta \\
(\%)\end{array}$ \\
\hline 400 & 3.70 & 4.02 & 7.44 \\
600 & 1.96 & 3.93 & 9.35 \\
800 & 1.79 & 3.99 & 9.80 \\
1000 & 1.35 & 4.00 & 6.05 \\
\hline
\end{tabular}

With increasing concentrations, the lin and Vin increased, which led to more electricity into heat consumed by PMS, so $\eta$ was deceased at high COD concentrations. Thus, when PMS was applied to collect MFC electricity, a balance should be made between charge time and energy harvesting efficiency.

\section{CONCLUSIONS}

Adding PMS to MFC circuit to replace resistors could increase performance of MFC in terms of CE, Vout, and Pout. The influent COD concentration of MFC was varied from 200 to $1000 \mathrm{mg} / \mathrm{L}$. The PMS had a positive effect on degrading organic by accelerating bacteria growth in MFCs, gaining higher $\mathrm{CE}$ than that with resistors. For MFC, the optimal influent COD concentration with highest CE (4.59\%) was $400 \mathrm{mg} / \mathrm{L}$. For PMS, the optimal energy harvesting efficiency was $7.44 \%$ at $400 \mathrm{mg} / \mathrm{L}$ of influent COD, while shortest charge time was $1.35 \mathrm{~h}$ at $1000 \mathrm{mg} / \mathrm{L}$. Overall, PMS increased performance of MFC, and $\mathrm{V}_{\text {out }}$ and $\mathrm{P}_{\text {out }}$ of the system were higher under intermittent MFC mode than those in continuous mode, which made MFC possible for real world applications.

\section{REFERENCES}

[1] B.E., Logan, B., Hamelers, R. Rozendal, Microbial fuel cells: methodology and technology, Environ. Sci. Technol. 40(17), 5181 (2006).

[2] A., Shantaram, H.B., R.R.A., Veluchamy, Z., Lewandowski, Wireless sensors powered by microbial fuel cells, Environ. Sci. Technol. 39 (13), 5037 (2005).

[3] H., Wang, J.D. Park, Z.J., Ren, Practical energy harvesting for microbial fuel cells: a review, Environ. Sci. Technol. 49, 3267 (2015).

[4] C., Donovan, A., Dewan, D., Heo, Z., Lewandowski, H., Beyena, Sediment microbial fuel cell powering a submersible ultrasonic receiver: New approach to remote monitoring, J. Power Sources 233, 79 (2013).

[5] J.,Wang, F.H., Bi, H.H., Ngo, W.S., Guo, H., Jia, H.W., Zhang, X.B., Zhang. Evaluation of energy-distribution of a hybrid microbial fuel cell-membrane bioreactor (MFC-MBR) for cost-effective wastewater treatment, Bioresour. Technol. 200, 420 (2016). 
[6] L.M., Tendera, S.A., Graya, E., Grovemanb, D.A., Lowyc, P., Kauffmand, J., Melhadoe, R.C., Tycef, D.,Flynnf, R., Petreccag, J., Dobarro, The first demonstration of a microbial fuel cell as a viable power supply: Powering a meteorological buoy, J. Power Sources 179 (2), 571 (2008). 